\title{
Researches on the higher valuation of sugar beet pulp from sugar production to obtain premixes for animal feed
}

\author{
Elena Mihaela Nagy *1, Constantin Coța $^{1}$, Nicolae Cioica ${ }^{1}$, Zoltan Gyorgy ${ }^{1}$ and Teodora \\ Deac $^{2}$ \\ ${ }^{1}$ INMA Bucharest, Branch Cluj-Napoca, 400436, 59 Al. Vaida Voievod Str., Cluj Napoca, Romania \\ ${ }^{2}$ Technical University of Cluj-Napoca, Faculty of Mechanical Engineering, 400641, 103-105 Muncii \\ Bdul, Romania
}

\begin{abstract}
The sugar beet pulp from the sugar production is, thanks to the easily assimilable carbohydrate content, an important source of feed, especially for polygastric animals. Its efficiency in terms of assimilation and biological effect can be substantially improved by the addition of macroelements $(\mathrm{Ca}, \mathrm{Mg}, \mathrm{P})$ and microelements $(\mathrm{Zn}, \mathrm{Co}, \mathrm{Fe}, \mathrm{Mn}, \mathrm{Cu})$. These elements react with the sugar beet pulp compounds to form specific chelates. In order to preserve and maintain the nutritional value of the premix, the realization process involves a drying operation. In view of this, experiments have been carried out to determine the maximum moisture content that ensures preservation and optimum drying conditions. This paper presents how the percentage of micro- and macro-elements used and the drying temperature influence the drying speed of the premix
\end{abstract}

\section{Introduction}

The pulp resulting from the technological process of sugar production by processing sugar beets represents a valuable feed with a high energy potential and increased efficiency in the nutrition of highly productive milk cows, bulls and rams on intensive fattening.

From the energy point of view, the nutritional value of the sugar beet pulp is approaching that of a good quality hay with the remark that it is assimilated much easier and with a superior efficiency: $90-95 \%$.

From a chemical point of view, the sugar beet pulp resulting from the sugar production process is a macromolecular complex of the beet cell membrane consisting of protopectin and represents $5 \%$ of the processed beet. The protopectin under the action of pectolytic enzymes in the digestive tract is hydrolysed, both in acidic and basic media, passing into pectinic acid and low molecular weight polypectins, soluble in water, which are absorbed easily and at high velocity [1-3].The nature and chemical structure of sugar beet pulp carbohydrates determines their easy transformation into compounds that enter into milk composition, with a positive effect on both the level of production and the fat content that increases by $8-11 \%$.

\footnotetext{
Corresponding author: nagy m2002@yahooco.uk
} 
Also the presence of sugar beet pulp in the feed ration of bulls and rams subjected to intensive fattening leads to the elevation of the qualitative level of proteins [4-11]. Highefficiency transformation of sugar beet pulp carbohydrates directly into useful compounds contributes to the sensitive reduction of greenhouse gas emissions (carbon dioxide and methane) produced by ruminants during digestion with positive effect on the environment [12] . Furthermore, the practice has shown that partial substitution of grains starch (corn, barley, etc.) with sugar beet pulp is beneficial as it increases efficiency of using the fibrous feed [12].

Although the addition of beet pulp in animals feed has important advantages, the practice has shown that there are still restrictions on the quantities administered since, longterm, both milk production and the metabolic health of animals can be affected [4].

The efficiency of beet pulp in the food ration of polygastric animals can be greatly improved by the addition of macroelements $(\mathrm{N}, \mathrm{P}, \mathrm{Ca}, \mathrm{Mg}$ ) and microelements, especially $\mathrm{Zn}^{2+}$, which has a positive effect on fertility and $\mathrm{Co}^{2+}$ that facilitates the synthesis of vitamins from complex $\mathrm{B}$ in the final intestinal tract. The presence of macroelements and microelements in fodder ration is beneficial [13] especially because by reacting with polyglucuronic acids, organo-mineral complexes are formed which facilitate the absorption of $\mathrm{Ca}^{2+}, \mathrm{Mg}^{2+}, \mathrm{PO}_{4}^{3+}$.

The seasonal functioning of sugar factories that processe sugar beets, correlated with the large quantities resulting as a by-product (5\% of the quantity of beet processed) requires pulp processing by drying for preservation over longer periods of time [13,14, 15].

In this paper we present an experimental study showing the influence of temperature and additions of macroelements $\left(\mathrm{Ca}^{2+}, \mathrm{Mg}^{2+}, \mathrm{PO}_{4}{ }^{3+}\right)$ and microelements $\left(\mathrm{Fe}^{3+}, \mathrm{Zn}^{2+}, \mathrm{Co}^{2+}\right.$, $\mathrm{Cu}, \mathrm{Mn}^{3+}$ ) on drying speed of the pulp resulting from sugar beet processing in sugar factories.

\section{Materials and methods}

The experimental study was carried out with sugar beet pulp resulting from TEREOS Romania Ludus sugar factory. As a source of $\mathrm{Ca}$ we used industrial lime, for $\mathrm{Mg}$ we used dolomite lime resulting from calcination of Vaslobeni dolomite in laboratory at $850{ }^{\circ} \mathrm{C}$. As phosphorus source (P) we used phosphoric acid $85 \%$ quality p.a. from NORDIC CHEMICALS Cluj Napoca. Microelements (Co, $\mathrm{Zn}, \mathrm{Mn}, \mathrm{Fe})$ were added as sulfates

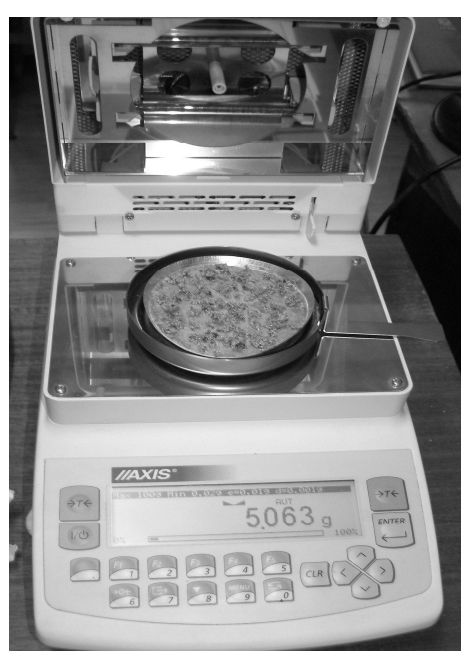
quality p.a. purchased from NORDIC CHEMICALS Cluj Napoca.

The drying study was carried out with a moisture analyzer AXIS 100, using thermo-gravimetrical method, The analyzer has a maximum capacity of $100 \mathrm{~g}$, precision weighing of $0,001 \mathrm{~g}$, precision humidity of $0,01 \%$, maximum drying temperature $160^{\circ} \mathrm{C}$ and heating by two halogen lamps (Fig. 1.). Samples of $5 \mathrm{~g}$ of four different compositions were subjected to drying at four different temperatures $\left(60,70,85\right.$ and $\left.95^{\circ} \mathrm{C}\right)$ : P1-pressed beet pulp, P2-pressed beet pulp with lime $\left(\mathrm{Ca}(\mathrm{OH})_{2}\right)$, P3-pressed beet pulp with lime and phosphoric acid $\left(\mathrm{H}_{3} \mathrm{PO}_{4}\right)$, respectively $\mathrm{P} 4$ pressed beet pulp with lime, phosphoric acid, dolomite lime $(\mathrm{CaOMgO})$ and microelements ( $\mathrm{Co}, \mathrm{Fe}, \mathrm{Mn}, \mathrm{Cu}, \mathrm{Zn}$ ).

Fig. 1. Moister analyzer AXIS 100 
Compositions, in organic parts, $\mathrm{CaO}, \mathrm{P}_{2} \mathrm{O}_{5}, \mathrm{MgO}$ and microelements, of the four samples subjected to drying, are shown in Table 1.

Table 1. Sample composition relative to dry matter

\begin{tabular}{|c|c|c|c|c|c|}
\hline Sample & $\begin{array}{c}\text { Organic parts } \\
{[\%]}\end{array}$ & $\begin{array}{c}\mathrm{CaO} \\
{[\%]}\end{array}$ & $\begin{array}{c}\mathrm{P}_{2} \mathrm{O}_{5} \\
{[\%]}\end{array}$ & $\begin{array}{c}\mathrm{MgO} \\
{[\%]}\end{array}$ & Microelements \\
\hline $\mathrm{P} 1$ & 18.7 & - & - & - & - \\
\hline $\mathrm{P} 2$ & 70 & 30 & - & - & - \\
\hline $\mathrm{P} 3$ & 65.63 & 28.5 & 5.85 & - & - \\
\hline $\mathrm{P} 4$ & 61.5 & 23.2 & 5.5 & 9.8 & $\begin{array}{c}\mathrm{Ca}=1.2 \mathrm{ppm} \\
\mathrm{Zn}=2.1 \mathrm{ppm} \\
\end{array}$ \\
& & & & & $\begin{array}{c}\mathrm{Cu}=0.75 \mathrm{ppm} \\
\mathrm{Fe}=1.5 \mathrm{ppm} \\
\mathrm{Mn}=0.25 \mathrm{ppm}\end{array}$ \\
& & & & & \\
\hline
\end{tabular}

The AXIS STAT software, with which the moisture analyzer is provided, allow to automatically measure the sample mass every two minutes as well as to collect and store the measured values on the PC connected to the moisture analyzer.

\section{Results and discussions}

The technological process of drying the sugar beet pulp resulting from sugar production is complex. It consists of several elementary processes: mass transformation (chemical reactions between carbohydrates and $\mathrm{CaO}, \mathrm{P}_{2} \mathrm{O}_{5}$ and $\mathrm{MgO}$ ), heat transformation (water evaporation, heat consumption on the evaporation surface), mass transfer (water vapor diffusion through crust of dry material to the external surface of the beet pulp particles, diffusion of water vapor from the external surface of the particle in the volume of the gaseous phase) and heat transfer (heat transfer from the heating agent to the external surface of the particle, heat transfer through the crust of dry material to the external surface of the still wet core).

Depending on the working conditions the drying process can be carried out after any of the elementary processes listed. Moreover, it is possible that the process takes place according to a combined model, under the conditions that two elementary processes have speed of the same order of magnitude $[16,17]$. Choosing the type of dryer, designing, automating, conducting with the computer and optimizing the drying process imply the knowledge of the law after which the drying process takes place. In order to elucidate these goals, experimental researches are needed to highlight how the main parameters influence the process. In this context, in the paper, the influence of temperature and additions of macro and microelements on drying was studied.

The diagrams in Fig. 2, 3, 4 and 5 show, in comparison, the drying curves for each sample $\mathrm{P} 1, \mathrm{P} 2, \mathrm{P}$ and $\mathrm{P} 4$ at different drying temperatures..

From these graphs we can observe both the moisture variation in time relative to the dry matter for four samples, at four temperatures, and the high influence that the drying temperature has on the time necessary for the complete elimination of humidity, time whose values are shown in Table 2. 


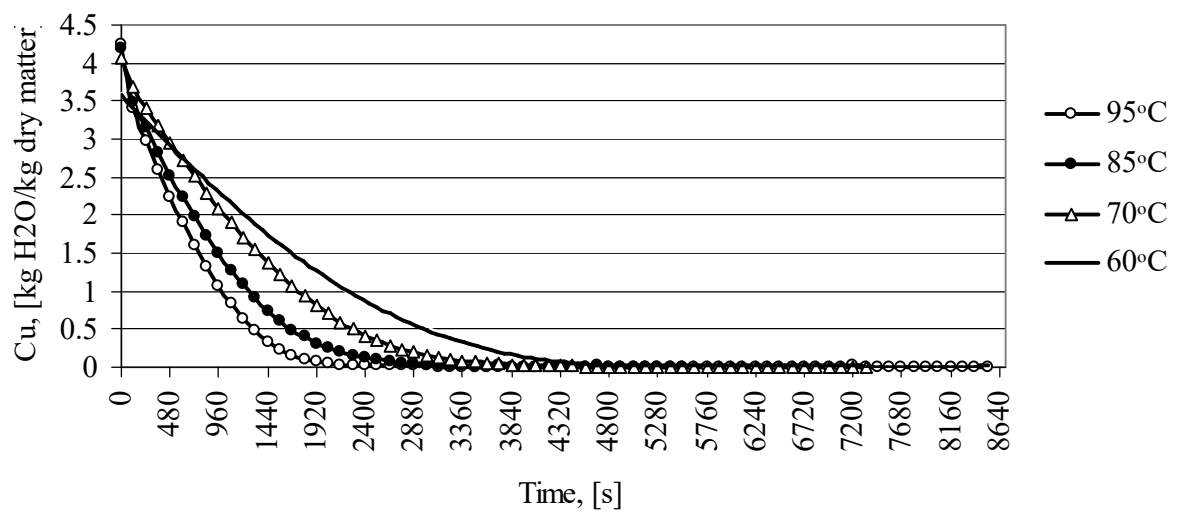

Fig.2. Drying curves for sample P1

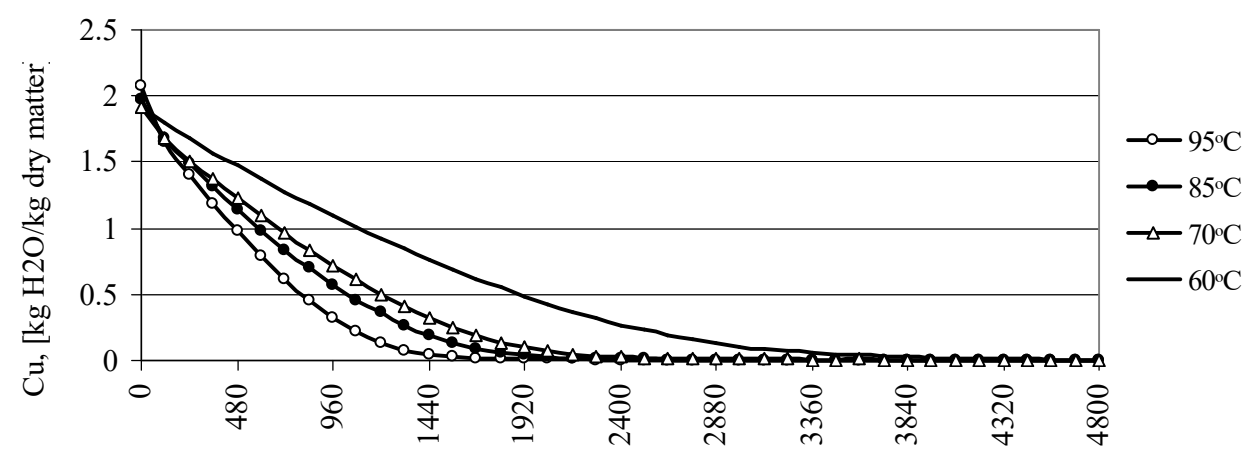

Time, [s]

Fig.3. Drying curves for sample P2

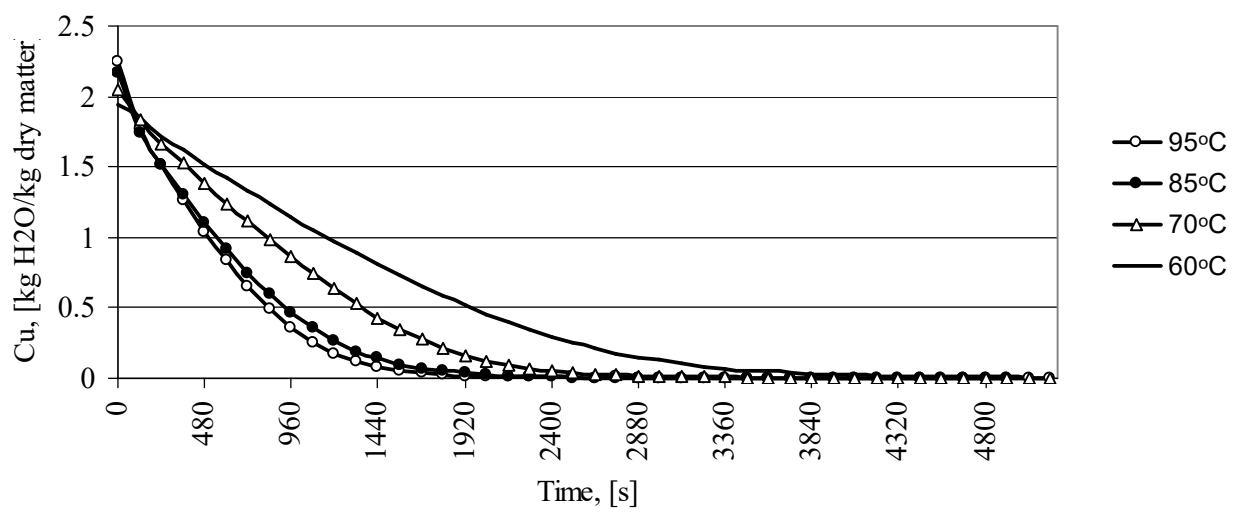

Fig.4. Drying curves for sample P3 


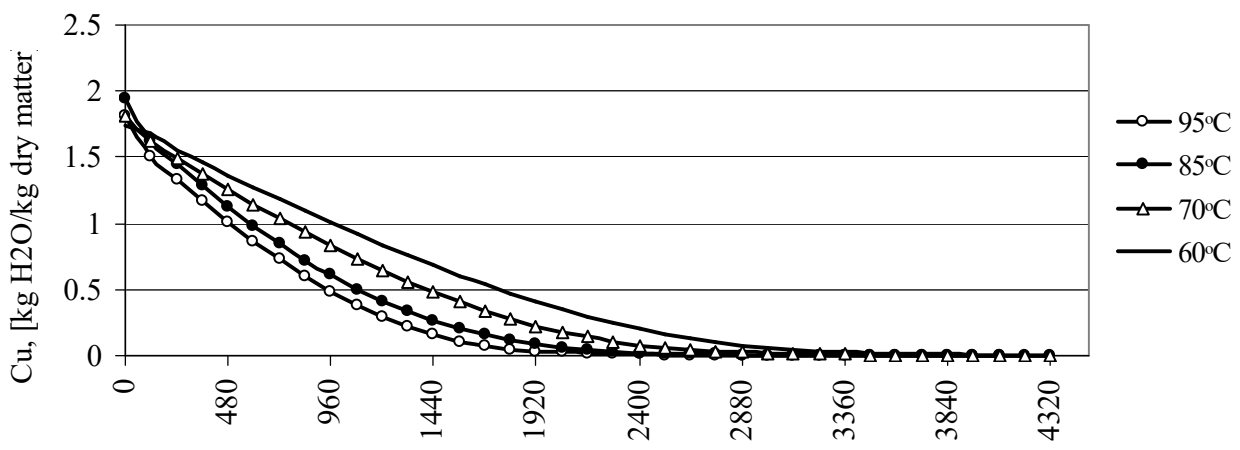

Time,[s]

Fig.5. Drying curves for sample P4

The moisture content of samples at any point during drying decreases as the drying temperature increases.

Table 2. Influence of temperature and additions on the time required to reach steady state

\begin{tabular}{|l|c|c|c|c|}
\hline Drying time, $[\mathrm{s}]$ & \multicolumn{4}{|c|}{$\tau$} \\
\hline Temp,$\left[{ }^{\circ} \mathrm{C}\right]$ & 60 & 70 & 85 & 95 \\
\hline P1 & 8400 & 4920 & 3720 & 3480 \\
\hline P2 & 4680 & 4320 & 3600 & 3360 \\
\hline P3 & 4560 & 4200 & 3360 & 3240 \\
\hline P4 & 4200 & 3720 & 2760 & 2400 \\
\hline
\end{tabular}

Table 2 shows that in case of sample P1 (pressed beet pulp), the increase in the drying temperature from $60^{\circ} \mathrm{C}$ to $70^{\circ} \mathrm{C}$ leads to a $40 \%$ reduction of the time required to completely eliminate the moisture. At temperatures above $70{ }^{\circ} \mathrm{C}$ this time decreases further but to a lesser extent.

Regarding the influence of the addition of macro and microelements on pressed beet pulp, we found that this is manifested especially at the drying temperature of $60^{\circ} \mathrm{C}$ for the sample P2 where the addition of lime leads to a $42 \%$ decrease of time required to reach the steady state. Addition of dolomite lime in P4 sample composition leads, at the same temperature, at a drying time necessary to reach the steady state by $50 \%$ lower than in the case of P1 sample. In the case of the other three temperatures the addition of lime and dolomite lime leads to $24-30 \%$ reductions of the time required to completely eliminate the moisture. The addition of phosphoric acid and microelements alters the duration of reaching the steady state of the drying process, but their influence is less pronounced.

It is noted that for all four compositions at $60^{\circ} \mathrm{C}$ the time required to reach the steady state is high and the value of this time at $95^{\circ} \mathrm{C}$ does not differ significantly from that at 85 ${ }^{\circ} \mathrm{C}$.

\section{Conclusions}

Addition of macro-elements (lime, dolomite lime and / or phosphoric acid) and microelements $(\mathrm{Co}, \mathrm{Fe}, \mathrm{Mn}, \mathrm{Cu}, \mathrm{Zn})$ in the feed premixes formula based on beet pulp resulting as a byproduct from the process of manufacturing sugar, positively influences its drying for preservation. 
The positive influence these additions have on the drying process can be explained by the fact that they modify the porous structure of the material, thus enhancing the internal water vapor diffusion processes.

The greater contribution of dolomite lime to reducing the time required to reach steady state, especially at low temperatures, is due to an exothermic reaction of dolomite lime with the water from the organic part of the premix, which speeds up its drying.

The optimal temperature at which the drying process of the premix must be carried out falls within the range of $70-85^{\circ} \mathrm{C}$. Temperatures in this area ensure both short drying times and therefore low energy consumption and preservation of the nutritional value of the premix. In this way, good efficiency can be obtained both at the drying of the sugar beet pulp premix for preservation and for the efficient use in feed rations of animals, especially polygastric animals.

\section{Acknowledgements}

This work was supported by a grant of the Romanian Research and Innovation Ministry, through Programme 1 - Development of the national research-development system, subprogram 1.2 - Institutional performance - Projects for financing excellence in RDI, contract no. 16PFE and by Contract 5N/07.02.2019.

\section{References}

1. F.N. Domsa, L. Iliescu, Tehnologia zaharului, (Ed.Tehnica, Bucuresti, 1973)

2. Z. Bubnik, P. Kadlec, D. Urban, Sugar Technologists Manual: Chemical and Physical Data for Sugar Manufacturers and Users, (Ed Bartens, Berlín, 1995)

3. A. Lenart, J.M. Flink, Int. J. of Food Sci. \& Tech., 19 (1), 45, (2007)

4. M. Münnich, F. Klevenhusen, Q. Zebeli, Animal Feed Sci. and Tech., 241, 75, (2018)

5. A.P.A. Monteiro, J.K. Bernard, J.R. Guo, X.S. Weng, S. Emanuele, R. Davis, G.E. Dahl, S.Tao, J. of Dairy Sci., 100 (2), 1063, (2017)

6. R.E. Rauch, P.H. Robinson, L.J., Erasmus, Animal Feed Sci. and Tech., 177 (3-4), 180, (2012)

7. A. Jokić, Z. Zavargo, N. Lukić, B. Ikonić, J. Marković, J. Dodić, J. Grahovac, J. on Proces. and Energy in Agri., 17 (1), 24, (2013)

8. Ch.V. Boucque, B.G. Cottyn, F.X. Buysse, Livestock Prod. Sci., 5 (2), 171, (1978)

9. M. Münnich, R. Khiaosa-ard, F. Klevenhusen, A. Hilpold, Q. Zebel, Animal Feed Sci. and Tech., 224, 78, (2017)

10. P. Kelly, Animal Feed Sci. and Tech., 8 (1), 1, (1983)

11. P. Ertl, Q. Zebeli, W. Zollitsch, W. Knaus, J Dairy Sci. 99 (2), 1228, (2016)

12. I. Sanchis, L. Luján, C. Ferreira, F. Martínez, Animal Prod. Sci., 55(1), 56 (2015)

13. M. A. Salgado, A. Lebert, H.S. Garcia, J. J. Bimbenet, Drying Tech. An Int. J., 12 (4), 955, (1994)

14. O. Levenspiel, Tehnica reactiilor in ingineria chimica, (Ed.Tehnica, Bucuresti, 1967)

15. L. Yang, Z.Hu, L.Yang, S. Xie, M. Yang, INMATEH-Agricultural Engineering, 55 (2), 53, (2018)

16. C. Calistru, C. Leonte, Tehnologia substantelor anorganice, (Ed. Didactica si Pedagogica, Bucuresti, 1972)

17. Z. Dancea, Nutriția animală şi elemente de nutrițiea omului, (Ed TODESCO, ClujNapoca, 2005) 